\title{
22. OPAL PHYTOLITHS FROM THE TROPICAL EASTERN PACIFIC OCEAN, DEEP SEA DRILLING PROJECT LEG 54
}

\author{
David Bukry, United States Geologic Survey, Scripps Institution of Oceanography, La Jolla, California
}

\section{INTRODUCTION}

Opal phytoliths are the silicified casts of epidermal cells of terrestrial grasses which have been described and illustrated from Atlantic Ocean sediment cores by Kolbe (1955) and Bukry (1979a, b), and from Mediterranean Sea cores by Dumitrică (1973) and Hajós (1973). The presence, in deep-sea sediments, of these microfossils of land plants has been attributed to wind transport on the basis of modern observations and analyses of dustfalls near Africa and across the Atlantic Ocean (Folger et al., 1967; Folger, 1970; and Kolbe, in part, 1957). The relative abundance and long duration of opal phytolith accumulation at the East Pacific Rise sites of Leg 54 seem to support eolian transport, rather than deposition by river and ocean currents.

The opal phytoliths from Leg 54 are more diverse than those of the Atlantic and are most abundant in the lower Quaternary of the sites at the Siqueiros fracture zone. Opal phytoliths are sparse or absent at the two sites cored east of the Galapagos Islands (Figure 1).

\section{DISCUSSION}

The recognition of abundant and persistent populations of opal phytoliths at the northern sites of Leg 54 in the upper Pliocene and lower Quaternary permits comparison with Leg 47A, Site 397, off northwest Africa, where opal phytoliths also occur through the upper Pliocene and Quaternary (Bukry, 1979a). Trade winds sweeping the grasslands and dry lakes of Africa have transported a mixture of opal phytoliths and freshwater diatom frustules out over the Atlantic (Folger, 1970), resulting in unexpectedly high concentrations of land-derived biogenic material far from the shoreline (Kolbe, 1955). The combination of continental aridity, climatic seasonality, and intensified winds that would contribute to such sediment transport must be linked to major climatic cycles. Dissolution of biogenic opal in marine settings (Mikkelsen, 1978) could also account for the wide fluctuations in opal phytolith abundance at Leg 47A and Leg 54 sites. However, Kolbe (1957) indicates that opal phytoliths are relatively dissolution resistant based on his deep-sea diatom studies.

Because the source terrain for the eastern Pacific opal phytoliths should be in proximity to account for the concentrations observed and should also be along the tract of prevailing trade winds blowing out of the northeast to the southwest, southern Mexico and Central America are the most likely source areas for lower Quaternary grasslands. Dispersal by marine currents or dissolution could have somewhat disrupted the pattern.
But it may be possible to reconstruct partially the paleowind and grasslands history of Central America by study of the distribution of opal phytoliths in marine sediment of the East Pacific Rise in this region. For study purposes, acid residues of East Pacific Rise calcareous pelagic sequences should yield higher concentrations of opal phytoliths than sequences closer to the source, because of the greater dilution effect of terrigenous detritus near the continental margin.

It is noteworthy that eastern Pacific phytolith collections differ from those of the Atlantic near Africa by the absence or paucity of fresh-water diatoms such as Melosira granulata and Stephanodiscus astrea. Because the eastern Pacific sediments are rich in marine diatoms, solution is discounted and a general lack of erodable lake bed sediment, and possibly less active winds, are indicated for Central America relative to northwest Africa in the early Quaternary.

This report is a preliminary documentation of the distribution of opal phytolith morphotypes in the eastern Pacific Ocean. The most abundant assemblages of opal phytoliths are preserved in the lower Quaternary upper Crenalithus doronicoides Zone and lower Gephyrocapsa oceanica Zone of coccoliths. There are several instances in upper Quaternary sediment (Sections 420-2-8 and 428-1-1) where silicoflagellates or diatoms are missing but opal phytoliths are present. Although silica dissolution is more severe in the upper sediment layers of Leg 54, Kolbe (1955) suggests that where freshwater diatom frustules had been dissolved, or where they were not available, opal phytoliths would provide a guide to identify land-derived sediment in the open ocean. When distribution charts, prepared exclusively for opal phytoliths, are available from other areas it will be possible to assess the value of opal phytoliths in marine geology and paleoclimatology.

\section{METHODS}

Opal phytoliths were counted at the same time that counts for silicoflagellates were done. The sample for both studies is a preparation that used heated hydrochloric acid and hydrogen peroxide to produce a cleaned acid residue which was rinsed in distilled water. Settling was used, instead of sieving, to preserve the whole fraction for statistical integrity. Strewn slides were counted at magnification $\times 320$ to $\times 800$ (mostly $\times 625$ ), using sequential mechanical stage traverses. The total number of opal phytoliths counted is dependent on the abundance of silicoflagellates, as well as the opal phytolith abundance, because all counts were directed at achieving optimum counts for silicoflagellates. Therefore, on- 


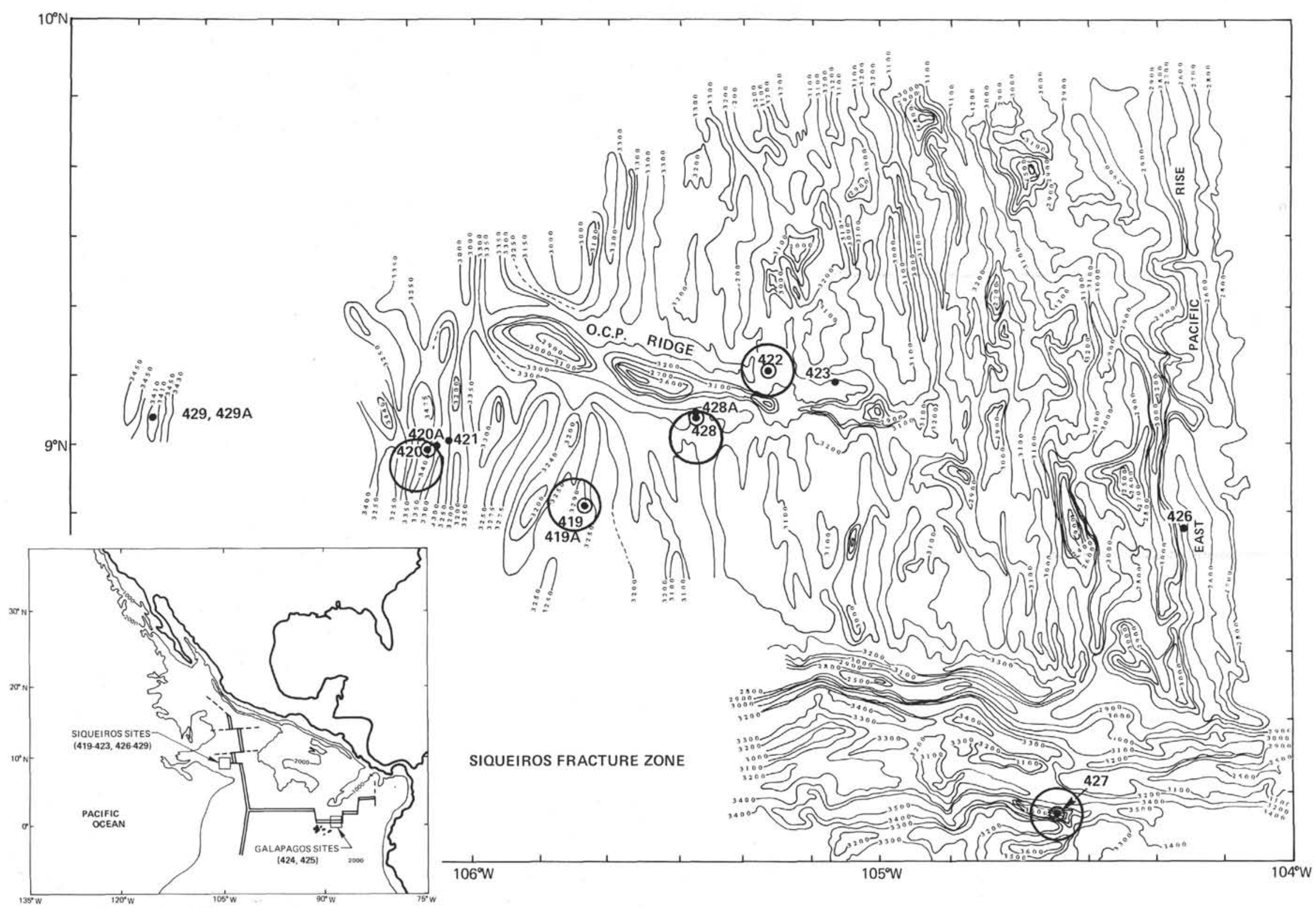

Figure 1. Leg 54 sites where significant accumulations of upper Pliocene and Quaternary opal phytoliths were recovered are circled. Bathymetry in meters; inset bathymetry in fathoms. 
ly one, or rarely two, $40 \times 22 \mathrm{~mm}$ slide areas were traversed. The greatest abundances of opal phytoliths in actual numbers and relative to silicoflagellates occur at Sites 420 and 428 , just north of the Siqueiros fraction zone (Tables 1 through 3 ).

\section{FORM AND NOMENCLATURE}

The descriptive nomenclature outlined in Twiss et al. (1969), Folger (1970), and Bukry (1979a) is the basis for that used here. Additional morphological details and the terminology of modern opal phytoliths are given by Metcalfe (1960) and Blackman (1971)

The assemblages of opal phytoliths from Leg 54 in the tropical eastern Pacific Ocean are diverse relative to those from the Atlantic Ocean. Variations of chloridoid and festucoid phytoliths are more common than in Legs 13, 47A, or 49. Although most Pacific elongate and panicoid phytoliths reiterate the forms known from the Miocene to Holocene of the Atlantic and Mediterranean, the Slant (Plate 1, Figure 6) and Tetrad (Plate 1, Figure 3) varieties of panicoid phytoliths from the Pacific have not been previously illustrated from DSDP cores.

Because it is difficult to distinguish some elongate opal phytoliths from sponge microscleres and corroded and abraded radiolarian fragments, the count for elongate phytoliths is fairly conservative.

\section{Panicoid Class}

These are the dumbbell-shaped opal phytoliths which are the most unequivocal and easily discerned evidence for the presence of opal phytoliths in marine sediment, especially in biogenous sediment which is replete with diverse opal microfossils and fragments from different marine organisms. Numerous variations in form and proportions even within the panicoid group can occur within a single grass species; for example, Blackman (1971, fig. 11) illustrates Danthonia parryi containing regular, stout, slim-rounded, and slim-truncate panicoids. The varieties of panicoid opal phytoliths identified from Leg 54 are preliminary divisions. Some references to previous illustrations are provided.

\section{Regular (Pa)}

(Plate 1, Figure 1; Plate 2, Figures 1-12, ?13-24)

Twiss et al., 1969, fig. 2, no. 3c, 3d.

Dumitricá, 1973, pl. 1, fig. $32,33,36,37,44,49$, and 50.

The periphery of the neck connecting the two bulbs is curved. The bulbs and neck may contain vesicles or small dark particles (carbon, pyrite?). The bulbs may be smooth, flat-ended, slightly indented, and may have small keels. On many specimens of Regular panicoids, when viewed obliquely, the rounded bulb outline is seen to be formed by two keels that flare out at the top and bottom of a more oblong solid. It is doubtful whether any of the bulbs, as seen in plan view, are solid

TABLE 1

Distribution of Opal Phytoliths and Diatom Melosira gramulata at Sites 419 and 420 (actual numbers of phytoliths encountered during traverses for silicoflagellate counts are recorded)

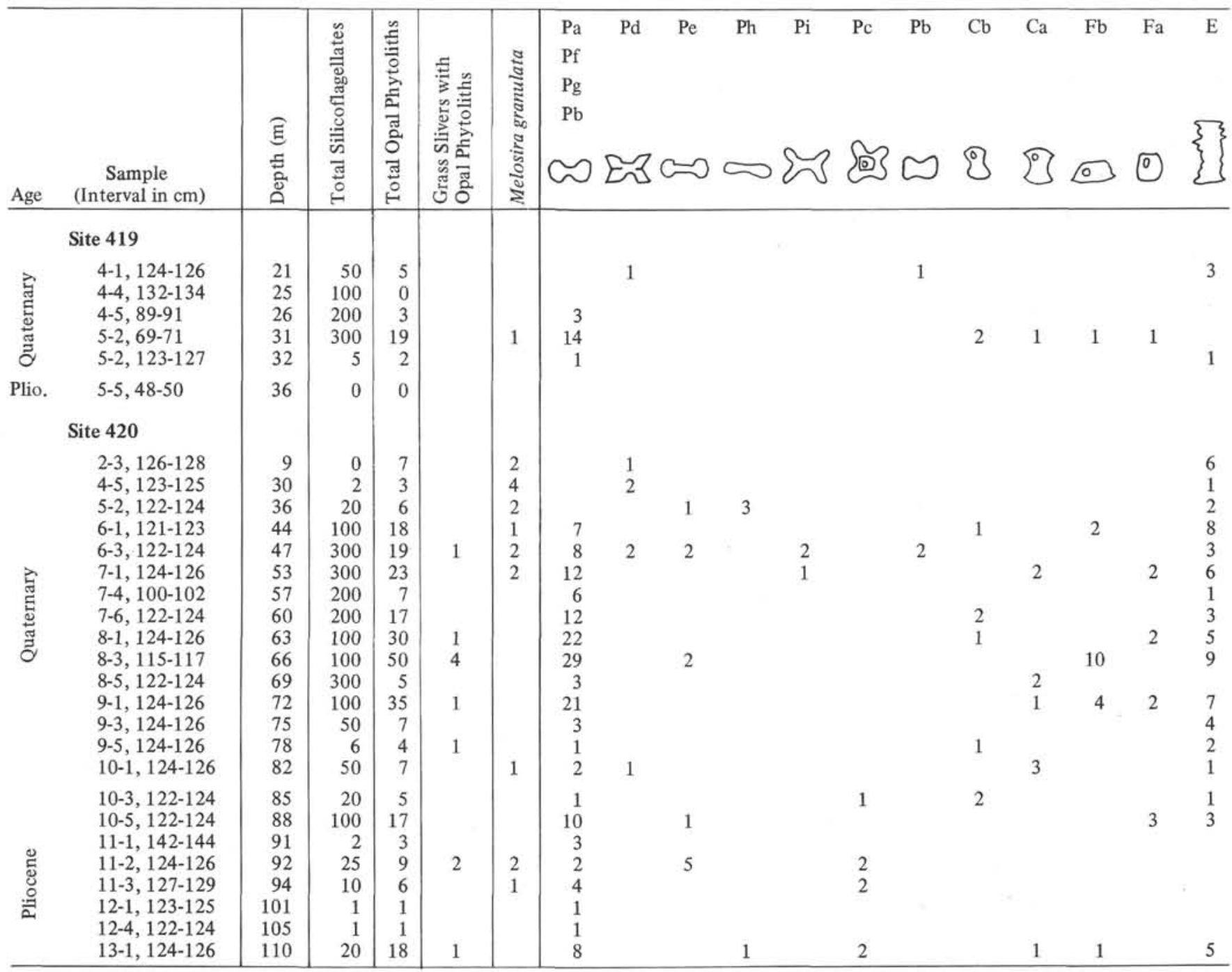


TABLE 2

Distribution of Opal Phytoliths and Diatom Melosira gramulata at Sites 422, 425, and 427 (actual numbers of phytoliths encountered during traverses for silicoflagellate counts are recorded, all samples are Quaternary)

\begin{tabular}{|c|c|c|c|c|c|c|c|c|c|c|c|c|c|}
\hline $\begin{array}{c}\text { Sample } \\
\text { (Interval in cm) }\end{array}$ & 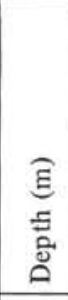 & 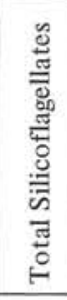 & 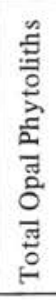 & 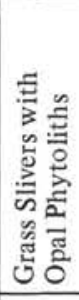 & 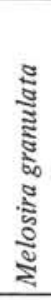 & $\begin{array}{l}\mathrm{Pa} \\
\mathrm{Pf} \\
\mathrm{Pg} \\
\mathrm{Pb}\end{array}$ & $\mathrm{ES}_{3}$ & & Pc & r & $\mathrm{Pj}$ & $\mathrm{Ca}$ & \{\} \\
\hline \multicolumn{14}{|l|}{ Site 422} \\
\hline $\begin{array}{l}3-6,125-126 \\
4-2,120-121 \\
4-3,120-121 \\
5-6,110-111 \\
8-1,100-101 \\
8-3,100-101\end{array}$ & $\begin{array}{l}24 \\
28 \\
30 \\
44 \\
50 \\
52\end{array}$ & $\begin{array}{r}1 \\
80 \\
18 \\
35 \\
50 \\
100\end{array}$ & $\begin{array}{r}1 \\
6 \\
1 \\
3 \\
0 \\
10\end{array}$ & & 1 & $\begin{array}{l}4 \\
1 \\
3 \\
5\end{array}$ & 1 & 2 & & 1 & 1 & 1 & 1 \\
\hline \multicolumn{14}{|l|}{ Site 425} \\
\hline $\begin{array}{l}1-2,110-112 \\
2-1,74-76 \\
2-3,74-76 \\
2-5,74-76 \\
3-4,74-76 \\
4-1,74-76 \\
4-2,74-76 \\
4-3,74-76\end{array}$ & $\begin{array}{r}3 \\
6 \\
9 \\
12 \\
30 \\
44 \\
46 \\
47\end{array}$ & $\begin{array}{l}300 \\
300 \\
200 \\
200 \\
200 \\
300 \\
300 \\
300\end{array}$ & $\begin{array}{l}0 \\
2 \\
2 \\
1 \\
1 \\
1 \\
1 \\
1\end{array}$ & & 1 & 2 & & & & & & 1 & $\begin{array}{l}2 \\
1\end{array}$ \\
\hline \multicolumn{14}{|l|}{ Site 427} \\
\hline $\begin{array}{l}3-2,70-72 \\
4-2,40-42 \\
8-5,7-8\end{array}$ & $\begin{array}{r}15 \\
34 \\
124\end{array}$ & $\begin{array}{l}50 \\
50 \\
20\end{array}$ & $\begin{array}{l}2 \\
5 \\
9\end{array}$ & & & $\begin{array}{l}1 \\
4 \\
3\end{array}$ & & & 1 & 1 & & 1 & $\begin{array}{l}1 \\
4\end{array}$ \\
\hline
\end{tabular}

TABLE 3

Distribution of Opal Phytoliths and Diatom Melosira granulata at Site 428 (actual numbers of phytoliths encountered during traverses for silicoflagellate counts are recorded, all samples are Quaternary)

\begin{tabular}{|c|c|c|c|c|c|c|c|c|c|c|c|c|c|c|c|}
\hline $\begin{array}{c}\text { Sample } \\
\text { (Interval in } \mathrm{cm} \text { ) }\end{array}$ & $\begin{array}{l}\widehat{\Xi} \\
\text { है } \\
\text { ڤ̆ }\end{array}$ & 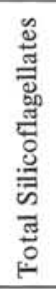 & 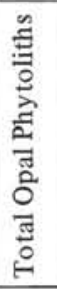 & 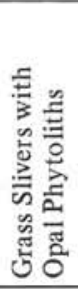 & 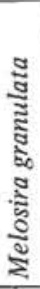 & $\begin{array}{l}\mathrm{Pa} \\
\mathrm{Pf} \\
\mathrm{Pg} \\
\mathrm{Pb}\end{array}$ & $\mathrm{Pd}$ & $\mathrm{Pc}$ & 0 & $\mathrm{Pj}$ & $\mathrm{Cb}$ & $\mathrm{Ca}$ & 0 & $\begin{array}{l}\mathrm{Fa} \\
0\end{array}$ & E \\
\hline $1-1,74-76$ & 1 & 0 & 2 & & & & & & 2 & & & & & & \\
\hline $2-3,74-76$ & 33 & 50 & 1 & & & & & & 1 & & & & & & \\
\hline $3-1,74-76$ & 39 & 100 & 25 & & & 14 & & & & & 5 & 5 & 1 & & \\
\hline $3-3,74-76$ & 42 & 300 & 1 & & & & & & & & & & & & 1 \\
\hline $3-5,74-76$ & 45 & 200 & 21 & & 1 & 7 & 2 & & & 2 & 2 & 2 & 1 & 2 & 3 \\
\hline $4-1,74-76$ & 49 & 100 & 18 & & 1 & 14 & & & 1 & 1 & & & & & 2 \\
\hline $4-3,74-76$ & 52 & 100 & 5 & & & 3 & & & 2 & & & & & & \\
\hline $4-5,74-76$ & 55 & 100 & 63 & 4 & & 47 & & 1 & 2 & 1 & 1 & 2 & & & 9 \\
\hline $5-1,74-76$ & 58 & 100 & 7 & & 1 & 4 & & & 1 & & & & & & 2 \\
\hline
\end{tabular}

spheroids. The illustrations presented here support the similar conclusion about keels on elongates, Regular panicoids and Trilobate panicoids discussed by Blackman (1971). Also, Metcalfe (1960) noted an uneven distribution of opal between the bulbs and the neck of panicoids at high and low focuses.

\section{Stout $(\mathbf{P b})$}

(Plate 1, Figure 2; Plate 2, Figures 25-30)

The neck is short and thick, and the ends of the bulb are usually flat. Slightly indented specimens are a link to the Tetrad $(\mathrm{Pc})$ variety because their oblong form is almost at the square, four-lobed format. Some transitional forms of Stout panicoids are tabulated with the Regulars.

\section{Tetrad (Pc)}

(Plate 1, Figure 3; Plate 3, Figures 1-9)

Twiss et al., 1969, fig. 2, no. 3a?

The Tetrad variety has four peripheral keeled lobes symmetric about a point in the center of a square-to-oblong solid opal. The corners of the central solid may extend within the lobes. The Tetrad varie- 
ty appears to be related to Regular panicoids through intermediate forms of indented Stout panicoids.

\section{Keeled (Pd)}

(Plate 1, Figure 4; Plate 3, Figures 10-12)

Dumitrică, 1973, pl. 1, fig. 45 .

Although clearly keeled, angular panicoid specimens appear distinctive in oblique view, their differentiation from the Regular panicoids may be questionable. Aside from the prominence of the keels, the specimens singled out from Leg 54 and by Dumitrica (1973) from the Mediterranean have indented ends and angular leading edges, resembling the feathering of an arrow.

Baton $(\mathbf{P e})$

(Plate 1, Figure 5; Plate 3, Figure 13)

- Sparse specimens having basically circular bulbs in plan view and a distinctive parallel-sided, long connecting neck are tabulated as Baton panicoids.

\section{Slant (Pf)}

(Plate 1, Figure 6; Plate 3, Figures 16-21)

Slant panicoids have the greatest diameter of the bulbs slanted to the axis of the connecting neck. Slant specimens were tabulated with Regular panicoids.

\section{Orthogonal (Pg)}

(Plate 1, Figure 7; Plate 3, Figures 14, 15)

Twiss et al., 1969, fig. 2, no. 3f?

Dumitrică, 1973 , pl. 1 , fig. 35 .

Orthogonal panicoids have oblong bulbs oriented with long axis perpendicular to the connecting neck. Orthogonals were tabulated with Regulars.

\section{Slim (Ph)}

(Plate 1, Figure 8; Plate 3, Figures 22-27)

Twiss et al., 1969, fig. 2, no. 3e.

Slim panicoids have the long axis of the bulb aligned with the neck axis. There is no sharp curve separating 'neck from bulb. The ends may be round or truncated.

\section{Bifid $(\mathbf{P i})$}

$$
\text { (Plate 1, Figure 9) }
$$

Twiss et al., 1969, fig. 2, no. 3b.

Sparse specimens that have a pronounced indentation of the bulb yielding a bifid termination are tabulated as Bifid.

\section{Trilobate $(\mathbf{P j})$}

(Plate 1, Figure 10; Plate 4, Figures 1, 2)

Metcalfe, 1960, fig. XXVII, no. 3.

Twiss et al., 1969, fig. 2 , no. $3 \mathrm{~g}-3 \mathrm{j}$.

Dumitrică, 1973, pl. 1, fig. 40 .

Sparse panicoid specimens having two and a half or three bulbs and two connecting necks along the same axis are tabulated as Trilobate.

\section{Chloridoid Class}

Small oblong-to-square format opal phytoliths having two concave and two convex margins, and some transitional forms, are tabulated in the Chloridoid Class. Most chloridoids have a prominent vesicle.

\section{Regular (Ca)}

(Plate 1, Figure 11; Plate 4, Figures 3-12)

Folger et al., 1967, fig. $2 \mathrm{~h}$.

Twiss et al., 1969, fig. 2 , no. $2 \mathrm{a}, 2 \mathrm{~b}$.

The square-to-oblong format and concave and convex sides, together with the usual large vesicle, gives a distinctive appearance to Regular chloridoid phytoliths. They are sparsely present at most of the Leg 54 sites.
Transitionals $(\mathbf{C b})$

(Plate 1, Figure 12; Plate 4, Figures 13-21)

Transitional chloridoids have less curvature than Regulars and approach the Festucoid Class (= cuboid).

\section{Festucoid Class}

Cuboid and oblong phytoliths usually having a vesicle and sometimes a small keel are a minor component of Leg 54 assemblages that is tabulated as Regular (Fa) (Plate 1, Figure 13; Plate 4, Figures 22-24) or slightly trapezoidal (Fb) (Plate 1, Figure 14; Plate 4, Figures $25,26)$.

\section{Elongate Class}

The simple rod shape and variable size and shape of protuberances make characterization and division of this class difficult. Although it is probably the most ubiquitous of opal phytolith forms, elongates mixed into marine sediments pose a special identification problem. Corroded silica rod structures of similar size and appearance may be produced from sponge and radiolarian skeletons. For this study a critical identification, requiring both characteristic outline and surface texture, was used to reduce such crossover. Therefore, the counts for elongates can be considered minima. For this reason, no subdivision into varieties was attempted. Representative specimens are illustrated (Plate 1, Figure 15; Plate 4, Figures 27-30; Plate 5, Figures 1-7).

\section{ACKNOWLEDGMENT}

I thank J. A. Barron and J. K. Crouch, U.S. Geological Survey, for helpful comments during this study. The manuscript was reviewed by J. A. Barron and R. Z. Poore, U.S. Geological Survey. I thank Dorothy Blackstock for expert proofing and typing of the manuscript. New insights into opal phytolith taxonomy for Leg 54 were provided through a recent paper by Deborah M. Pearsall (1978, Phytolith analysis of archeological soils: Evidence for maize cultivation in formative Ecuador, Science, v. 199, p. 177-178) showing archeologic applications for opal phytoliths. The samples from Leg 54 were kindly made available by Roger Hekinian and B. R. Rosendahl, Co-Chief Scientists.

\section{REFERENCES}

Blackman, E., 1971. Opaline silica bodies in the range grasses of southern Alberta, Canadian Journal of Botany, v. 49, p. 769-781.

Bukry, D., 1979a. Comments on opal phytoliths and stratigraphy of Neogene silicoflagellates and coccoliths at Deep Sea Drilling Project Site 397 off northwest Africa. In Luyendyk, B. P., Cann, J. R., et al., Initial Reports of the Deep Sea Drilling Project, v. 49: Washington (U.S. Government Printing Office), p. 977-1010.

1979b. Coccolith and silicoflagellate stratigraphy, northern Mid-Atlantic Ridge and Reykjanes Ridge, Deep Sea Drilling Project Leg 49. In Luyendyk, B. P., Cann, J. R., et al., Initial Reports of the Deep Sea Drilling Project, v. 49: Washington (U.S. Government Printing Office), p. 551-582.

Dumitricà, P., 1973. Phytolitharia. In Ryan, W. B. F., Hsü, K. J., et al., Initial Reports of the Deep Sea Drilling Project, v. 13: Washington (U.S. Government Printing Office), p. $940-943$.

Folger, D. W., 1970. Wind transport of land-derived mineral, biogenic, and industrial matter over the North Atlantic, Deep-Sea Research, v. 17, p. 337-352.

Folger, D. W., Burckle, L. H., and Heezen, B. C., 1967. Opal phytoliths in a North Atlantic dust fall, Science, v. 155, p. 1243-1244. 
Hajós, M., 1973. The Mediterranean diatoms. In Ryan, W. B. F., Hsü, K. J., et al., Initial Reports of the Deep Sea Drilling Project, v. 13: Washington (U.S. Government Printing Office), p. 944-969.

Kolbe, R. W., 1955. Diatoms from equatorial Atlantic cores, Swedish Deep-Sea Expedition Reports, v. 7, p. 150-184.

1957. Fresh-water diatoms from Atlantic deep-sea sediments, Science, v. 126, p. 1053-1056.
Metcalfe, C. R., 1960. Anatomy of the Monocotyledons. I. Gramineae: Oxford (Clarendon Press), p. 656-661, 700713.

Mikkelsen, N., 1978. Preservation of diatoms in glacial to Holocene deep-sea sediments of the equatorial Pacific, Geo$\log y$, v. 6, p. 553-555.

Twiss, P. C., Suess, E., and Smith, R. M., 1969. Morphological classification of grass phytoliths, Soil Science Society of America Proceedings, v. 33, p. 109-115.

\section{PLATE 1}

Classification of Opal Phytoliths and Melosira granulata

from Leg 54, Eastern Pacific Ocean.

Figures 1-9, 11-19 magnified $\times 800$; scale bar equals $10 \mu \mathrm{m}$.

Figure 10 magnified $\times 1050$; scale bar equals $10 \mu \mathrm{m}$.

Figure 20 magnified $\times 350$; scale bar equals $20 \mu \mathrm{m}$.

Figure 1

Figure 2

Figure 3

Figure 4

Figure 5

Figure 6

Figure 7

Figure 8

Figure 9

Figure 10

Figure 11

Figure 12

Figure 13

Figure 14

Figure 15

Figures $16-18$

Figure 19

Figure 20
Regular panicoid (Pa). Sample 427-8-5, 7-8 cm (124 m).

Stout panicoid $(\mathrm{Pb})$. Sample 420-6-1, 121-123 cm (44 m).

Tetrad panicoid (Pc). Sample 420-11-2, 124-126 cm (92 m).

Keeled panicoid (Pd). Sample 420-6-3, 122-124 cm (47 m).

Baton panicoid (Pe). Sample 420-11-2, 124-126 cm (92 m).

Slant panicoid (Pf). Sample 420-10-5, 122-124 cm (88 m).

Orthogonal panicoid (Pg). Sample 420-13-1, 124-126 cm (110 m).

Slim panicoid (Ph). Sample 420-5-2, 122-124 cm (36 m).

Bifid panicoids (Pi). Sample 420-6-3, 122-124 cm (47 m).

Tribolate panicoid ( $\mathrm{Pj})$. Sample 428-4-5, 74-76 cm (55 m).

Regular chloridoid (Ca). Sample 420-13-1, 124-126 cm (110 m).

Transitional chloridoid (Cb). Sample 420-11-2, 124-126 cm (92 m).

Regular festucoid (Fa). Sample 419-5-2, 69-71 cm (31 m).

Trapezoidal festucoid (Fb). Sample 425-5-4, 74-76 cm (68 m).

Elongate (E). Sample 420-6-3, 122-124 cm (47 m).

Melosira granulata (Ehrenberg) s. ampl.

16. Sample 428-3-5, $74-76 \mathrm{~cm}(45 \mathrm{~m})$.

17. Sample 425-4-3, 74-76 cm (47 m).

18. Sample 420-11-3, 127-129 cm (94 m).

Sliver of grass showing two stomata remnants and interstomatal cell sites of potential elongate opal phytolith formation by silica filling. Sample 428-4-5, 74-76 cm (55 m).

Elongate and panicoid phytoliths (arrows) in an acid residue strewn slide of Sample 428-4-5, 74-76 cm (55 m). 
PLATE 1
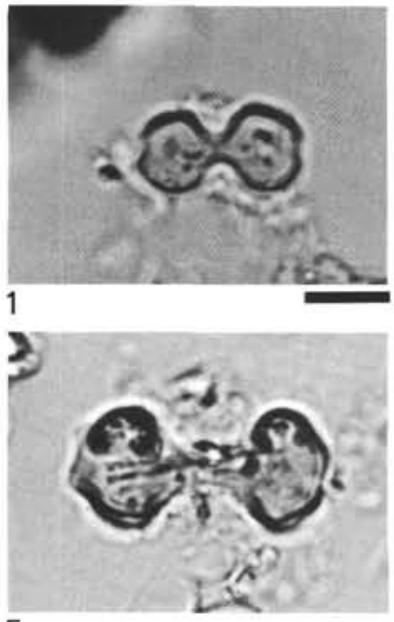

5

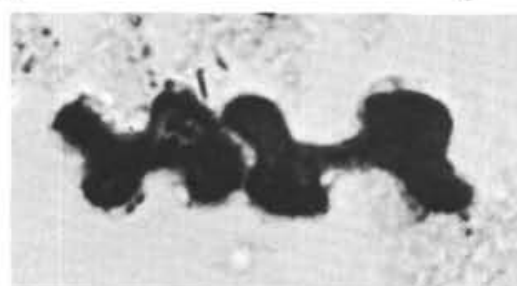

9

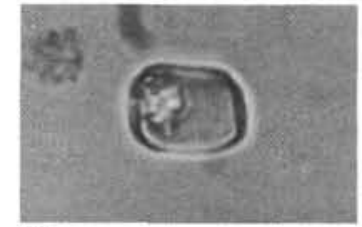

13
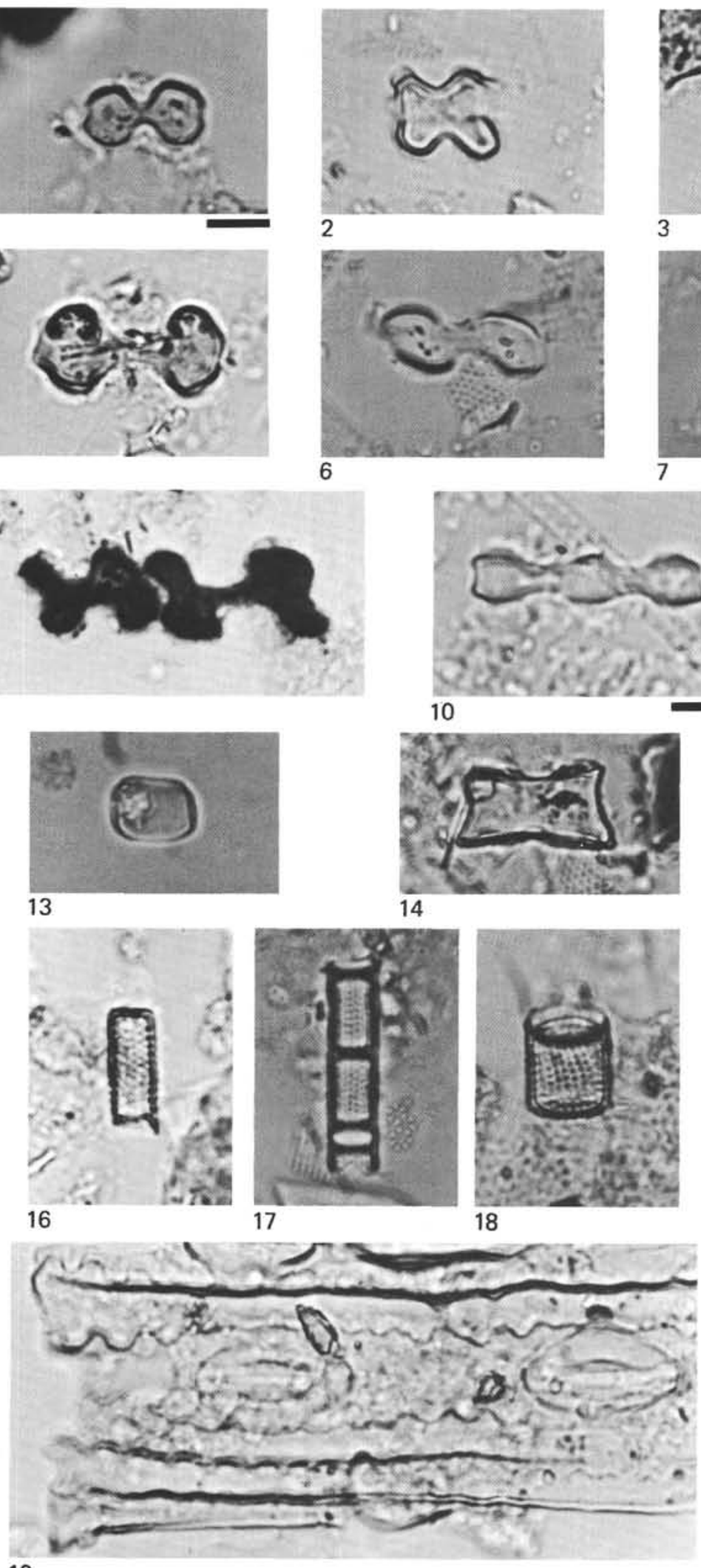

6
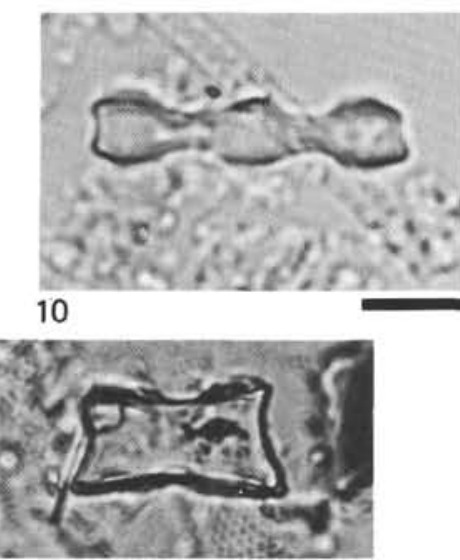

14
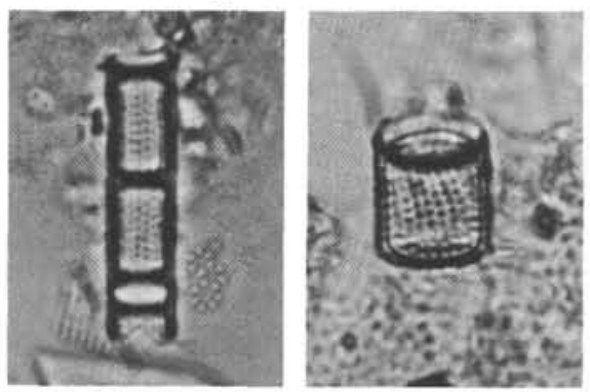

18

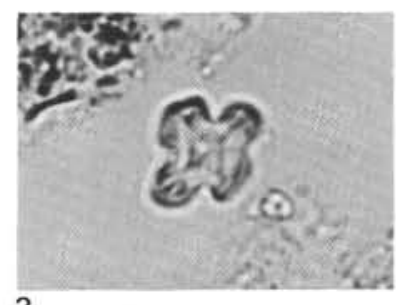

3
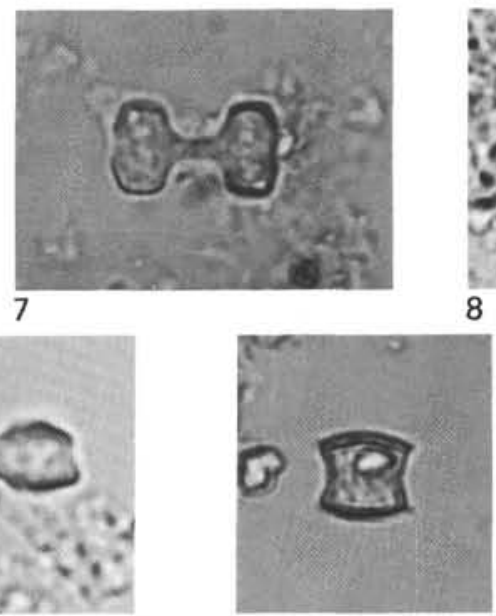

11

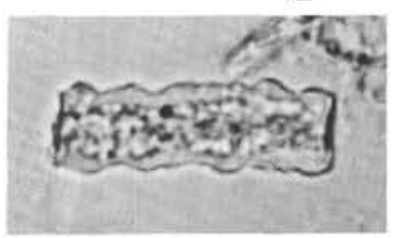

15

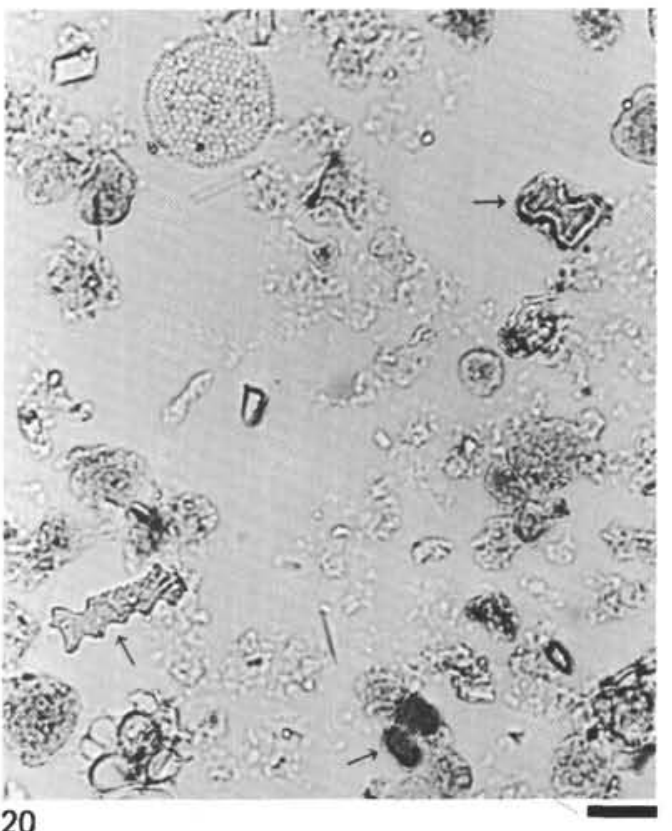




\section{PLATE 2}

Panicoid Opal Phytoliths from DSDP Leg 54.

Figures 1-25, 27-30 magnified $\times 800$; scale bar equals $10 \mu \mathrm{m}$.

Figure 26 magnified $\times 1050$; scale bar equals $10 \mu \mathrm{m}$.

Figures 1-12 Regular panicoids.

1. Sample 419-4-5, 89-91 cm (26 m).

2. Sample 428-3-1, 74-76 cm (39 m).

3. Sample $420-13-1,124-126 \mathrm{~cm}(110 \mathrm{~m})$.

4. Sample 420-7-4, 100-102 cm (57 m).

5 , 8. Sample 420-8-3, $115-117 \mathrm{~cm}(66 \mathrm{~m})$.

6 , 10. Sample 420-8-1, 124-126 cm (63 m).

7. Sample 420-11-2, $124-126 \mathrm{~cm}(92 \mathrm{~m})$.

9. Sample 420-7-1, 124-126 cm (53 m).

11. Sample 419-5-2, 123-127 cm (32 m).

12. Sample 420-8-5, $124-126 \mathrm{~cm}(69 \mathrm{~m})$.

Figures 13-24 Regular (specimens transitional to Stout panicoids with thicker and shorter necks). 13, 24. Sample 428-4-1, 74-76 cm (49 m). 14,23 . Sample 420-6-3, $122-124 \mathrm{~cm}(47 \mathrm{~m})$. 15,20 . Sample 428-4-5, 74-76 cm (55 m). 16,22 . Sample $419-5-2,123-127 \mathrm{~cm}(32 \mathrm{~m})$. 17,21 . Sample $428-3-5,74-76 \mathrm{~cm}$ (45 m). 18 , 19. Sample 428-3-1, $74-76 \mathrm{~cm}$ ( $39 \mathrm{~m})$.

Figures 25-30 Stout panicoids.

25. Sample 420-11-1, 142-144 cm (91 m).

26. Sample 428-4-5, 74-76 cm (55 m).

27. Sample 419-4-5, 89-91 cm (26 m).

28. Sample 428-3-1, 74-76 cm (39 m).

29. Sample $428-4-3,74-76 \mathrm{~cm}(52 \mathrm{~m})$.

30. Sample 419-5-2, 69-71 cm (31 m). 
PLATE 2
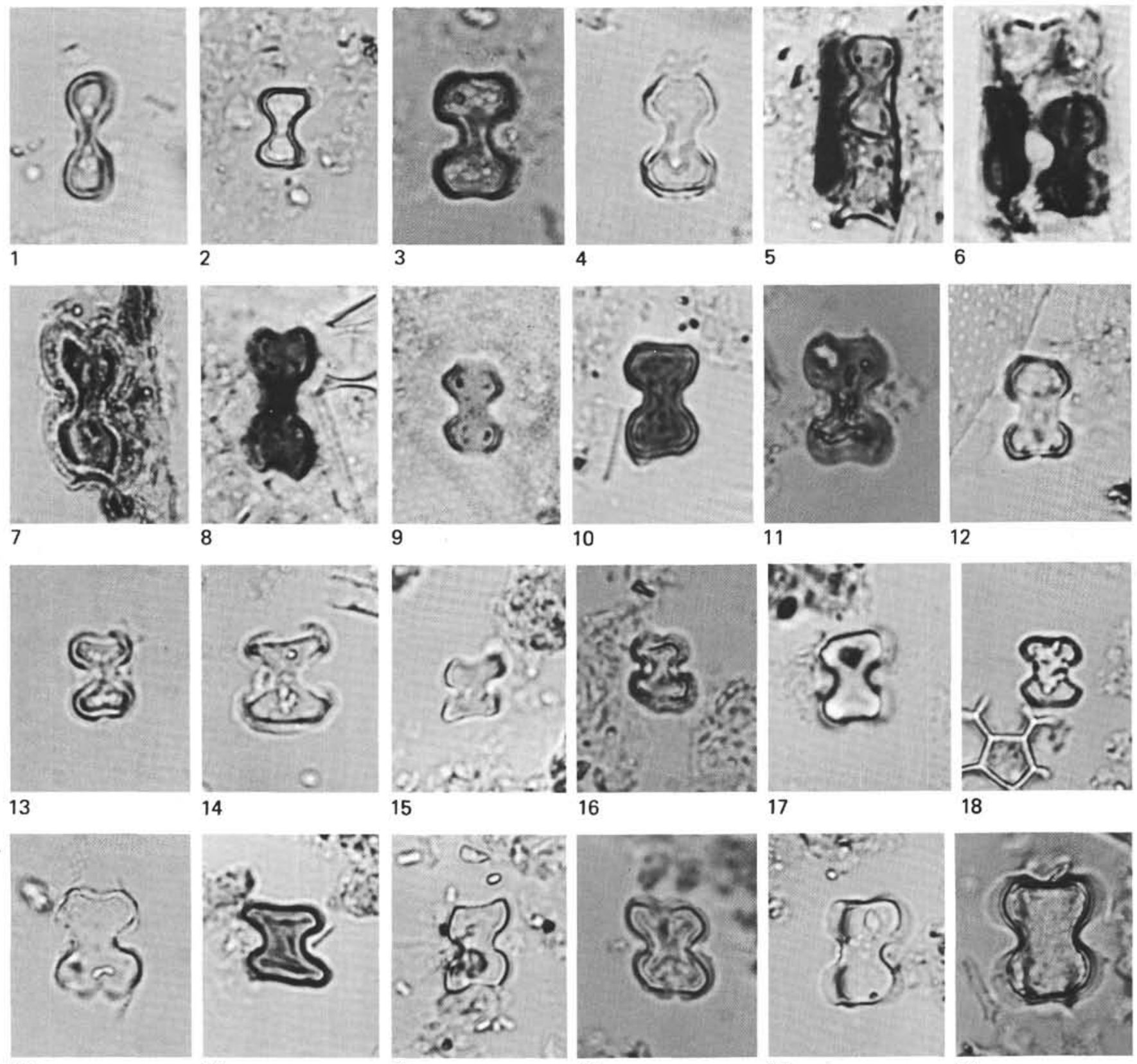

19

$$
20
$$

$$
21
$$

22
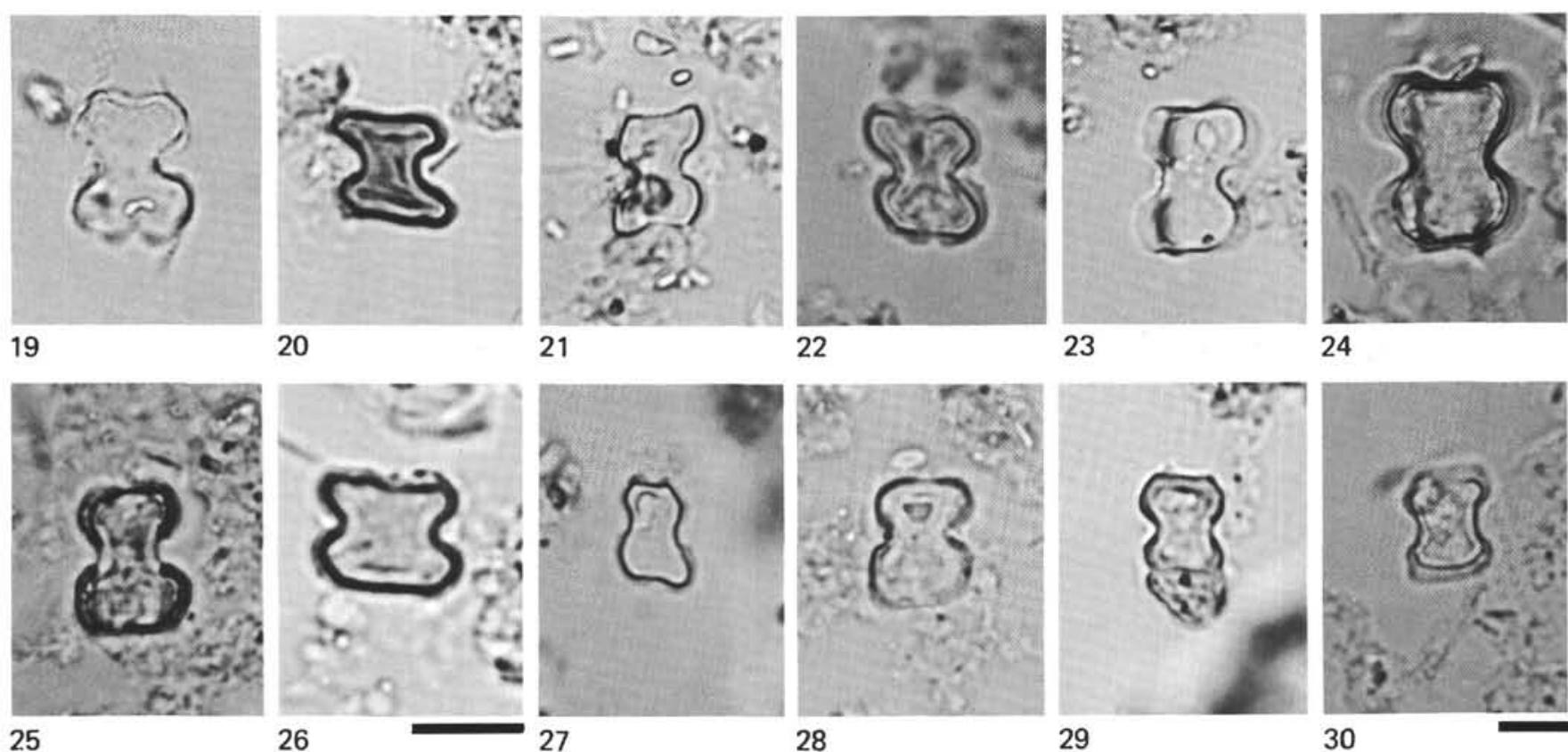

23

24
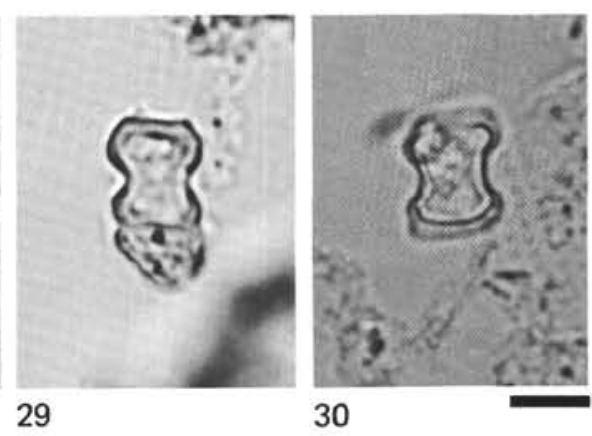


\section{PLATE 3}

Panicoid Opal Phytoliths from DSDP Leg 54.

Figures 1-2, 4-27 magnified $\times 800$; scale bar equals $10 \mu \mathrm{m}$.

Figure 3 magnified $\times 1050$; scale bar equals $10 \mu \mathrm{m}$.

Figures 1-9 Tetrad panicoids.

1. Sample 420-6-3, 122-124 cm (47 m).

2, 8. Sample 420-13-1, 124-126 cm (110 m).

3. Sample 428-4-5, 74-76 cm (55 m).

4. Sample 420-9-1, 124-126 cm (72 m).

5. Sample 420-11-2, 124-126 cm (92 m).

6. Sample $420-10-3,122-124 \mathrm{~cm}(85 \mathrm{~m})$.

7, 9. Sample $420-11-3,127-129 \mathrm{~cm}(94 \mathrm{~m})$.

Figures 10-12 Keeled panicoids.

10. Sample 428-3-1, 74-76 cm (39 m).

11. Sample 420-9-1, 124-126 cm (47 m).

12. Sample $420-6-3,122-124 \mathrm{~cm}(47 \mathrm{~m})$.

Figure 13 Baton panicoids.

Sample 428-4-5, 74-76 cm (55 m).

Figures 14, 15 Orthogonal panicoids.

14. Sample 420-8-3, $115-117 \mathrm{~cm}(66 \mathrm{~m})$.

15. Sample 420-5-2, 122-124 cm (36 m).

Figures 16-21 Slant panicoids.

16. Sample $422-4-2,120-122 \mathrm{~cm}(28 \mathrm{~m})$.

17. Sample 425-4-3, 74-76 cm (47 m).

18. Sample 420-10-5, $122-124 \mathrm{~cm}(88 \mathrm{~m})$.

19. Sample 420-11-2, $124-126 \mathrm{~cm}$ (92 m).

20. Sample 420-9-1, $124-126 \mathrm{~cm}$ (72 m).

21. Sample 428-4-1, 74-76 cm (49 m).

Figures 22-24 Slim-rounded panicoids.

22. Sample 428-4-1, 74-76 cm (49 m).

23. Sample 420-13-1, 124-126 cm (110 m).

24. Sample 428-3-1, 74-76 cm (39 m).

Figures 25-27 Slim-truncate panicoids.

25. Sample $420-9-5,124-126 \mathrm{~cm}$ (78 m).

26. Sample 419-4-1, 124-126 cm (21 m).

27. Sample 420-8-1, 124-126 cm (63 m). 
PLATE 3
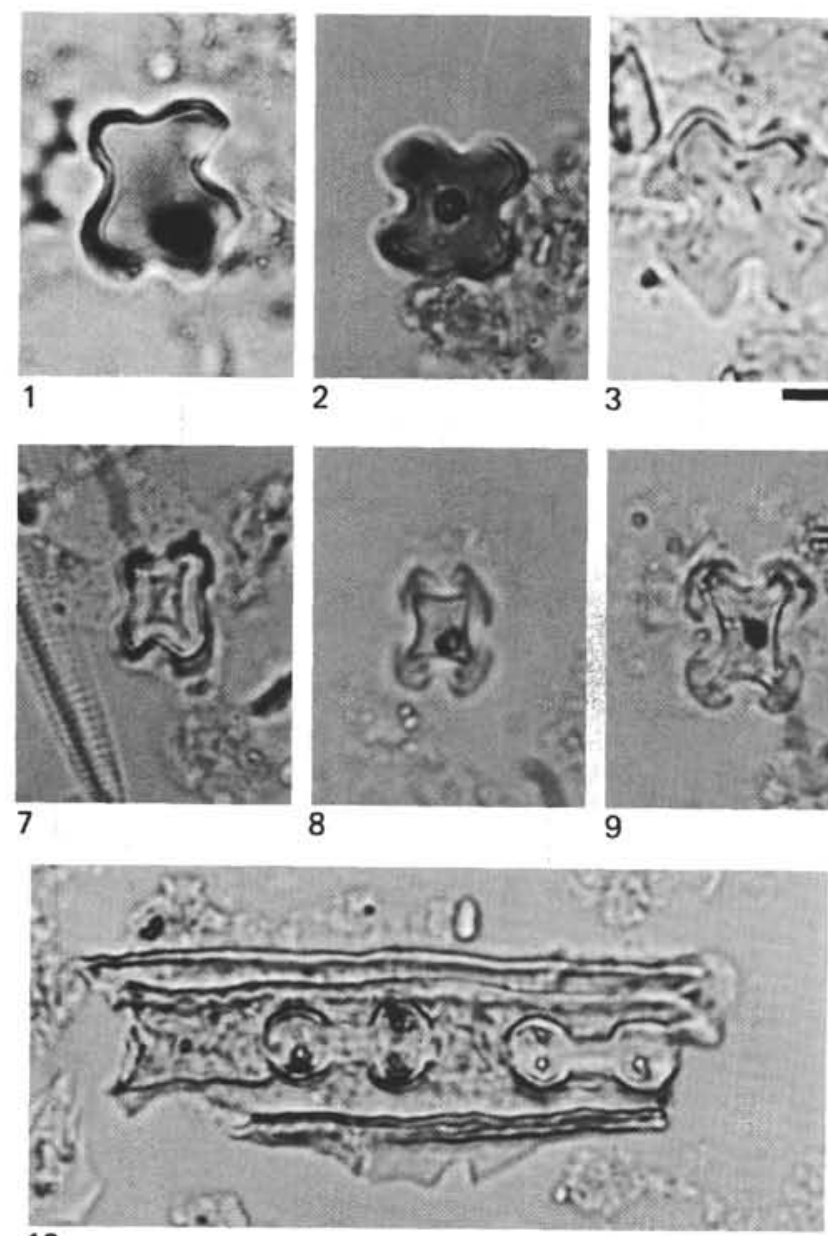

13

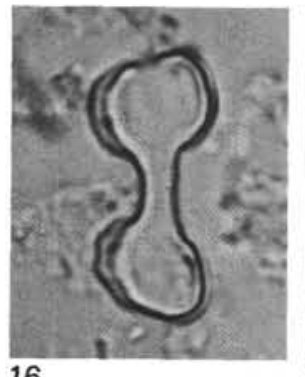

16

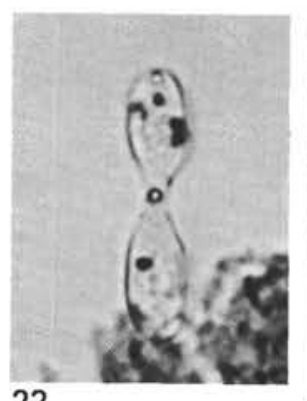

22
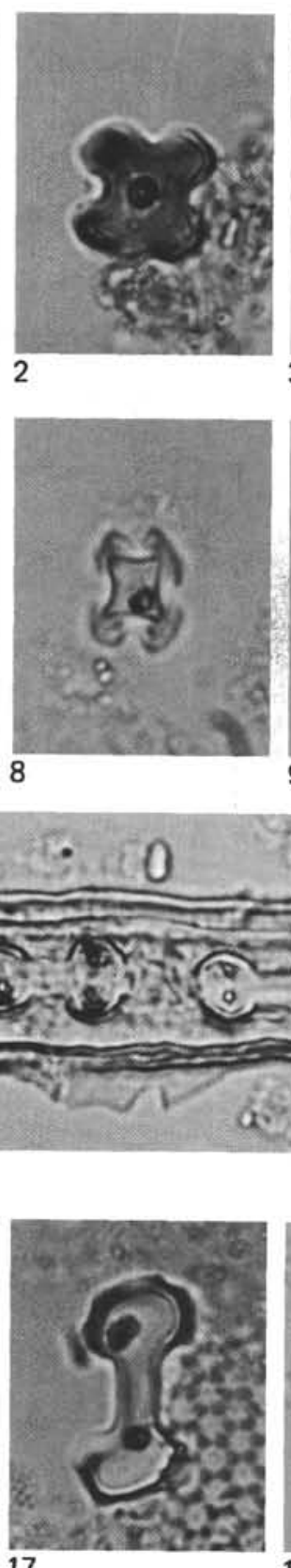

17

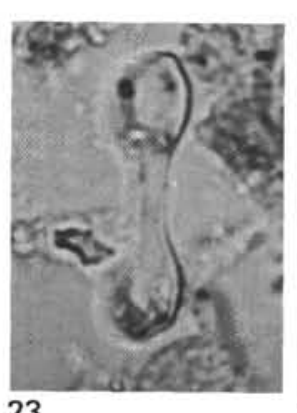

23
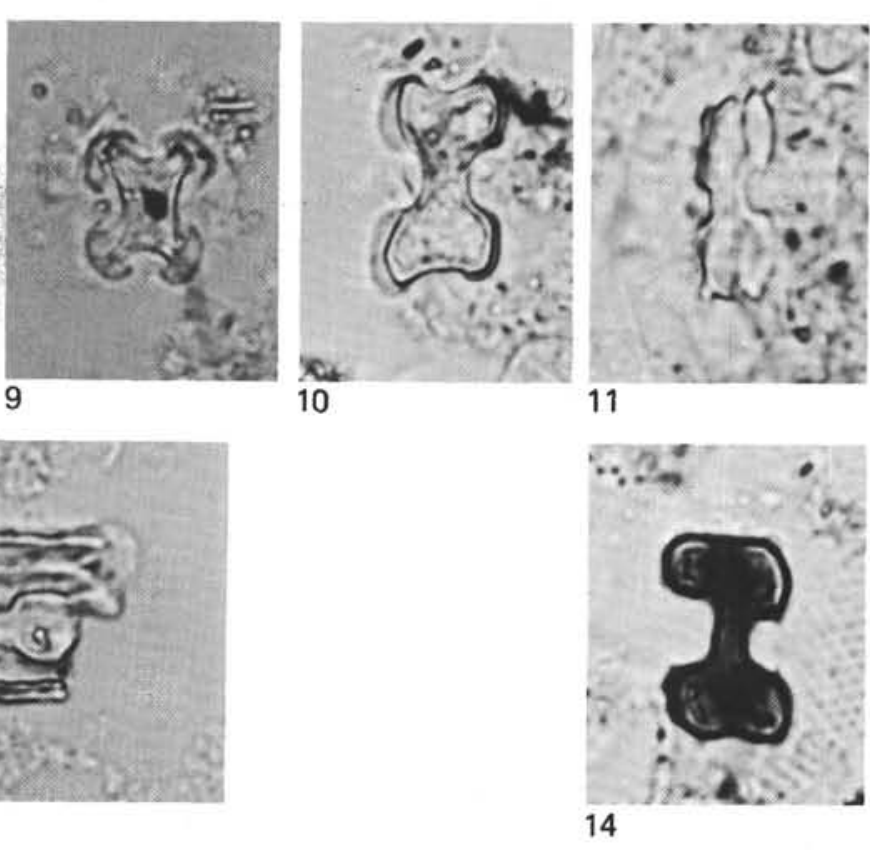

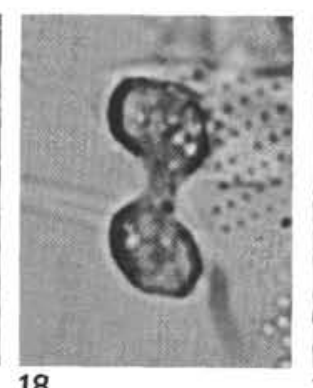

18

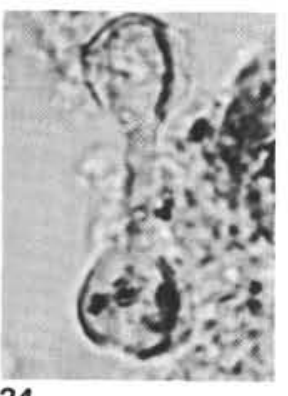

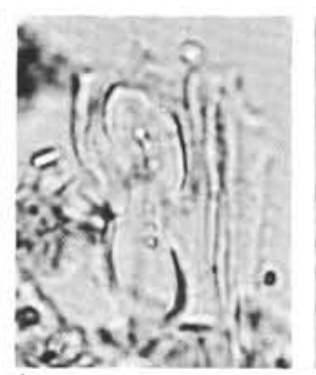

19

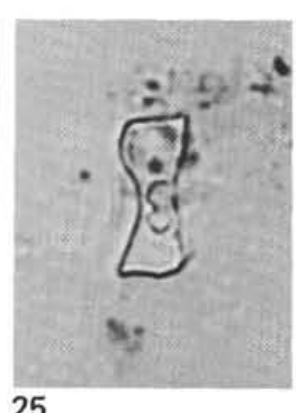

25

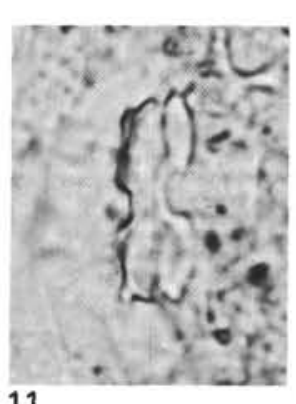

\section{1}
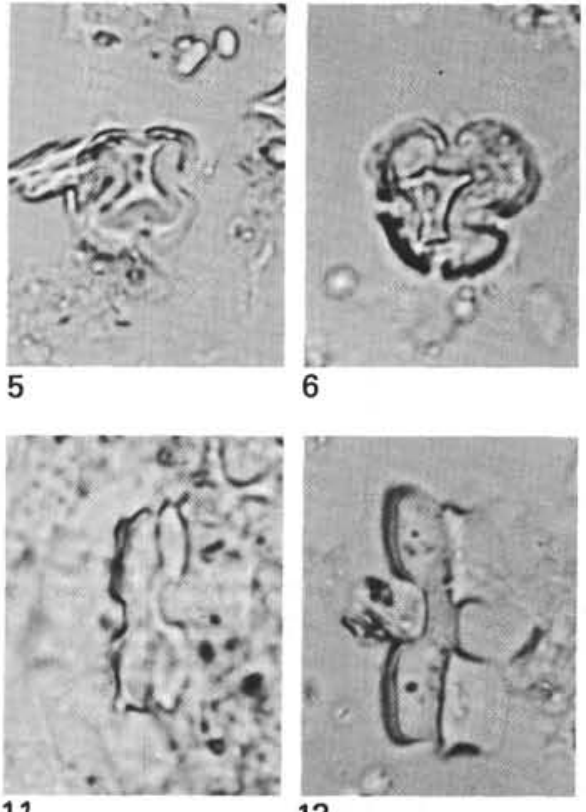

12

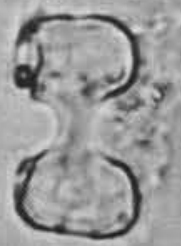

15
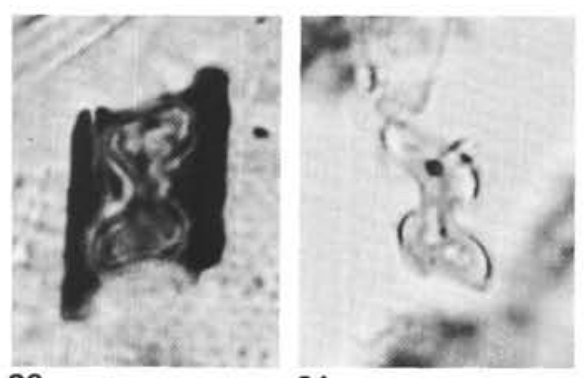

21

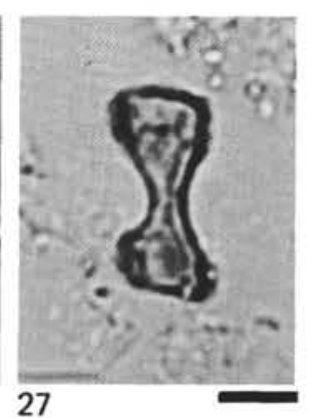


PLATE 4

Opal Phytoliths from DSDP Leg 54.

All figures magnified $\times 800$; scale bar equals $10 \mu \mathrm{m}$.

Figures 1, 2 Trilobate panicoids.

Sample 428-3-5, 74-76 cm (45 m).

Figures 3-12 Regular chloridoids.

3. Sample 420-8-1, 124-126 cm (63 m).

4. Sample $420-7-1,124-126 \mathrm{~cm}(53 \mathrm{~m})$.

5, 6. Sample 420-9-1, 124-126 cm (72 m).

7. Sample $420-10-5,122-124 \mathrm{~cm}(88 \mathrm{~m})$.

8. Sample $420-8-5,122-124 \mathrm{~cm}(69 \mathrm{~m})$.

9. Sample 428-3-1, 74-76 cm (39 m).

10. Sample $425-4-1,74-76 \mathrm{~cm}(44 \mathrm{~m})$.

11. Sample 420-10-1, 124-126 cm (82 m).

12. Sample $422-4-2,120-121 \mathrm{~cm}(28 \mathrm{~m})$.

Figures 13-21 Transitional chloridoids.

13, 19. Sample 420-8-3, 115-117 cm (66 m).

14. Sample 420-7-1, 124-126 cm (53 m).

15, 21. Sample 420-6-3, 122-124 cm (47 m).

16. Sample $428-2-3,74-76 \mathrm{~cm}(33 \mathrm{~m})$.

17. Sample 428-3-1, 74-76 cm (39 m).

18. Sample 419-5-2, 69-71 cm (31 m).

20. Sample 428-3-5, 74-76 cm (45 m).

Figures 22-24 Regular festucoids (= cuboids).

22. Sample $420-10-5,122-124 \mathrm{~cm}$ (88 m).

23. Sample $427-8-5,7-8 \mathrm{~cm}$ (124 m).

24. Sample $420-10-3,122-124 \mathrm{~cm}$ ( $85 \mathrm{~m})$.

Figures 25, 26 Trapezoidal festucoids.

25. Sample 420-6-3, 122-124 cm (47 m).

26. Sample 420-9-1, 124-126 cm (72 m).

Figures 27-30 Elongates.

27. Sample 420-6-3, $122-124 \mathrm{~cm}$ (47 m).

28 , 29. Sample 420-9-1, 124-126 cm (72 m).

30. Sample $427-8-5,7-8 \mathrm{~cm}$ (124 m). 
PLATE 4
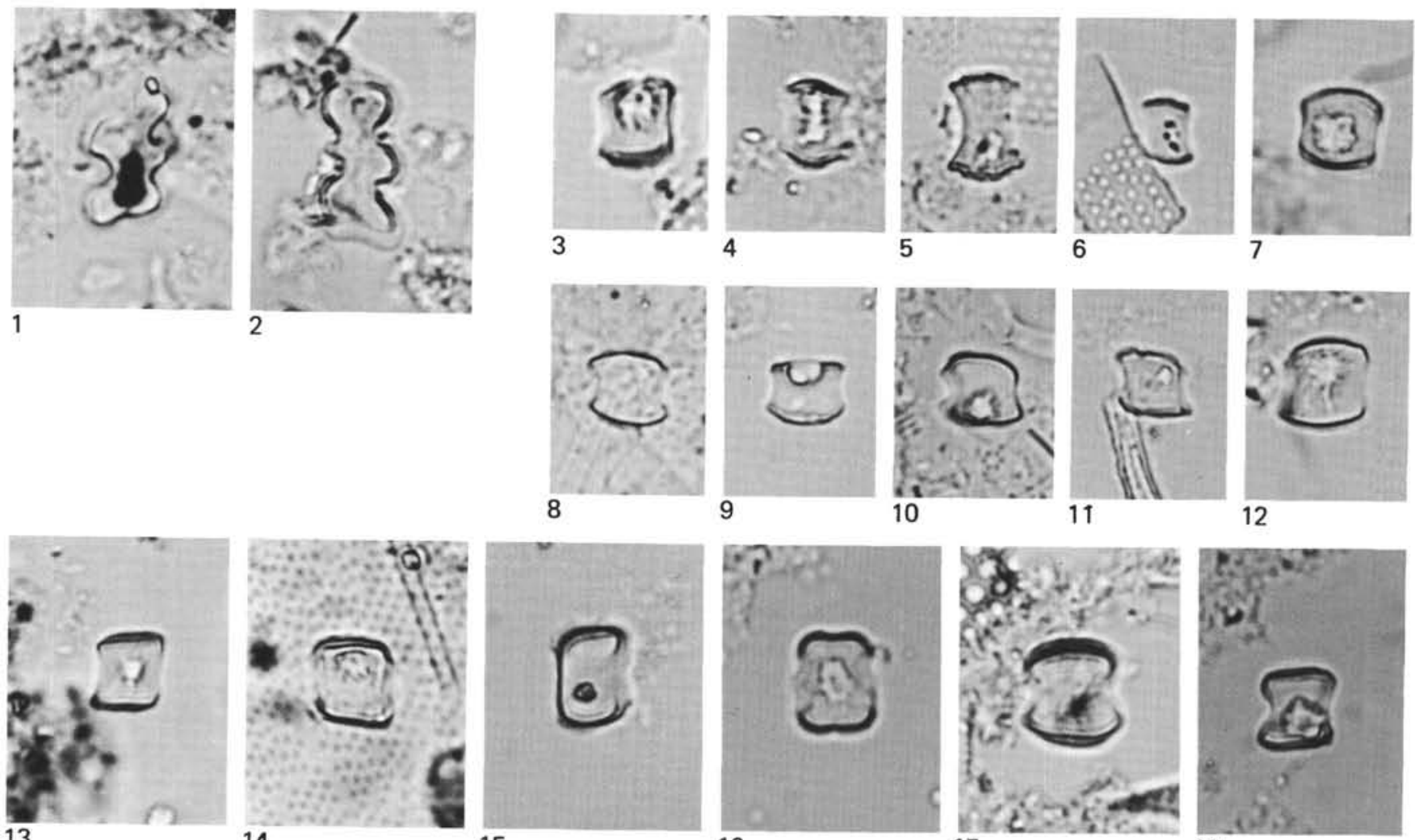

11

12
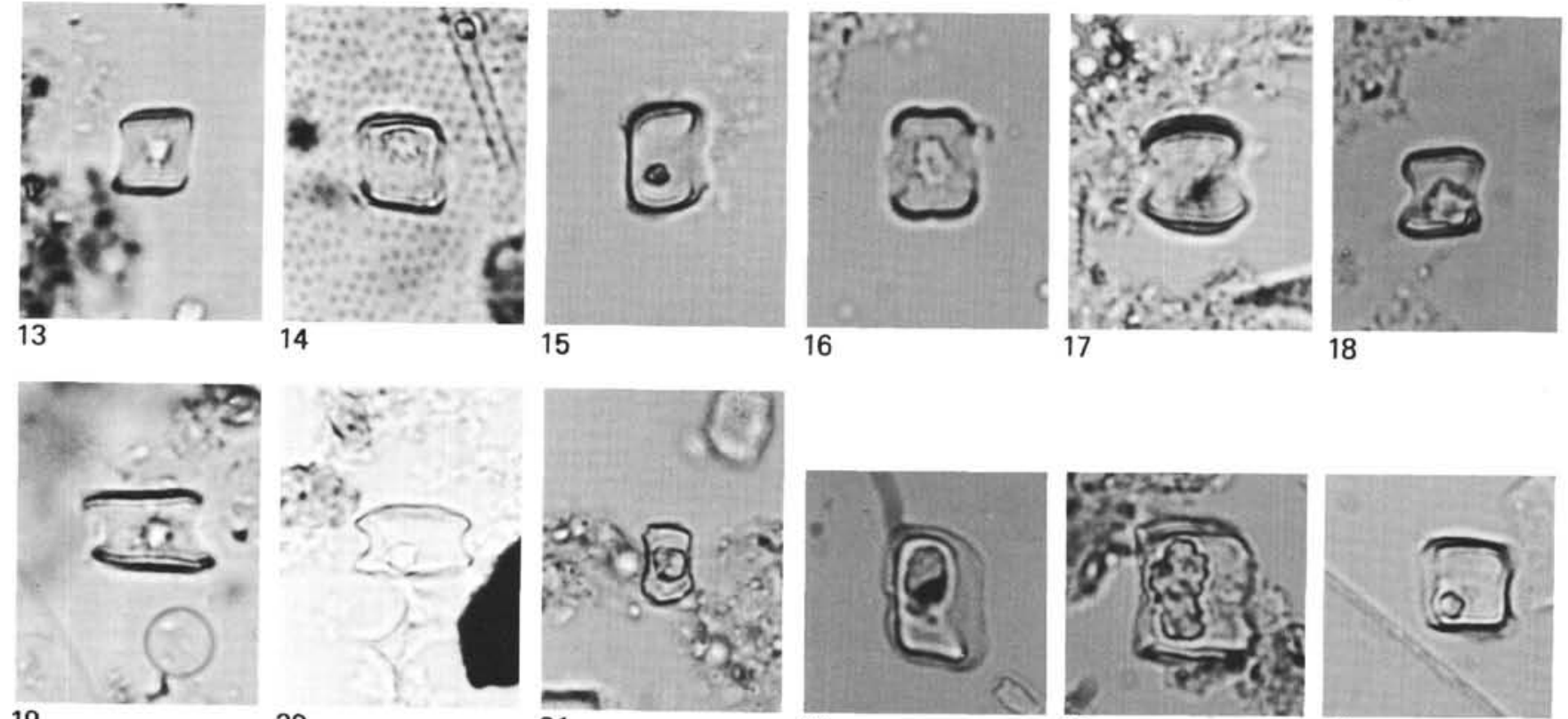

16

18

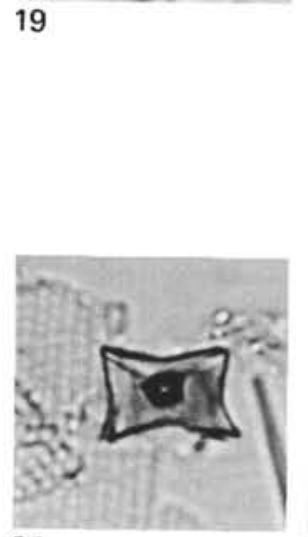

20
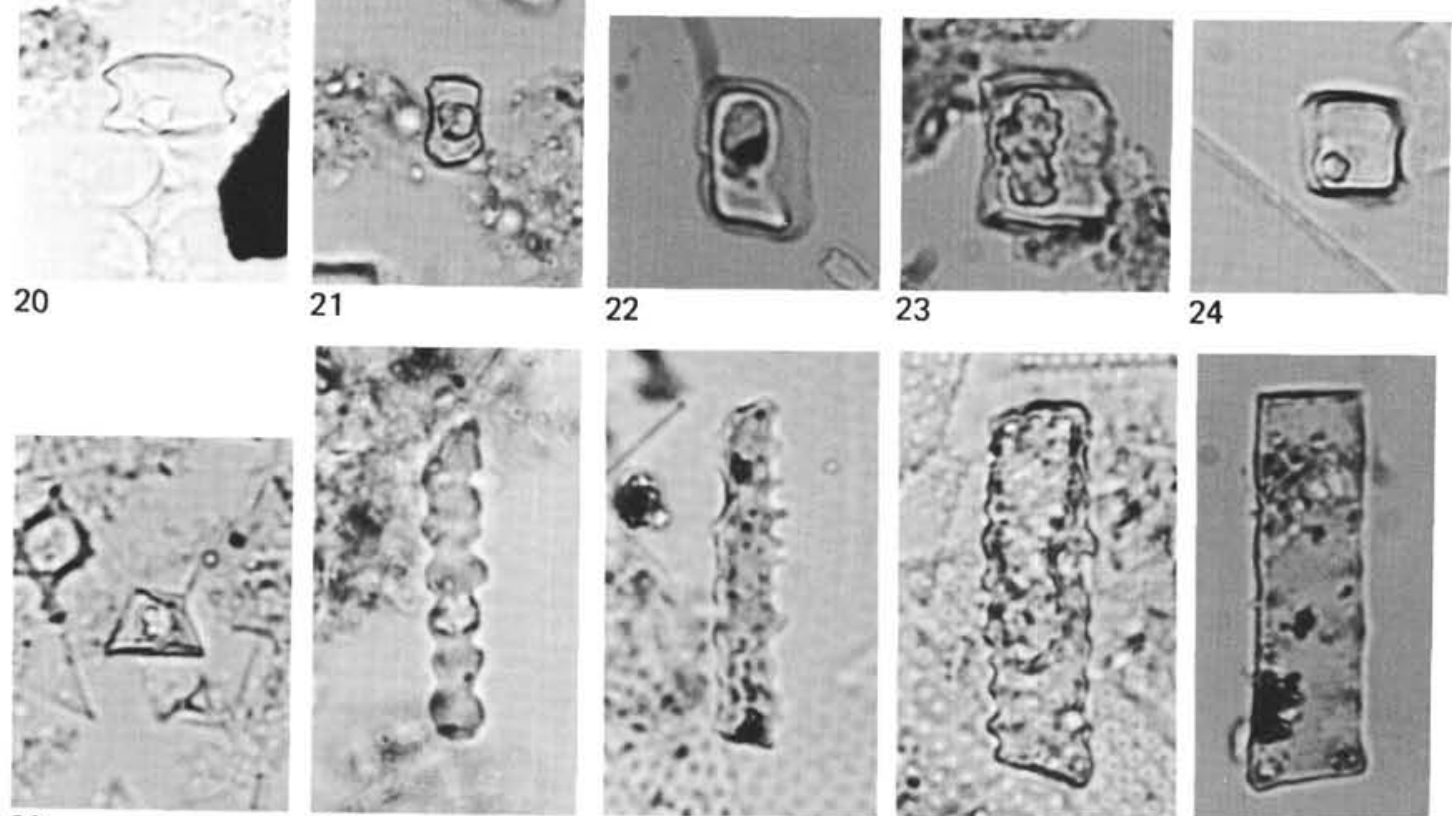

26
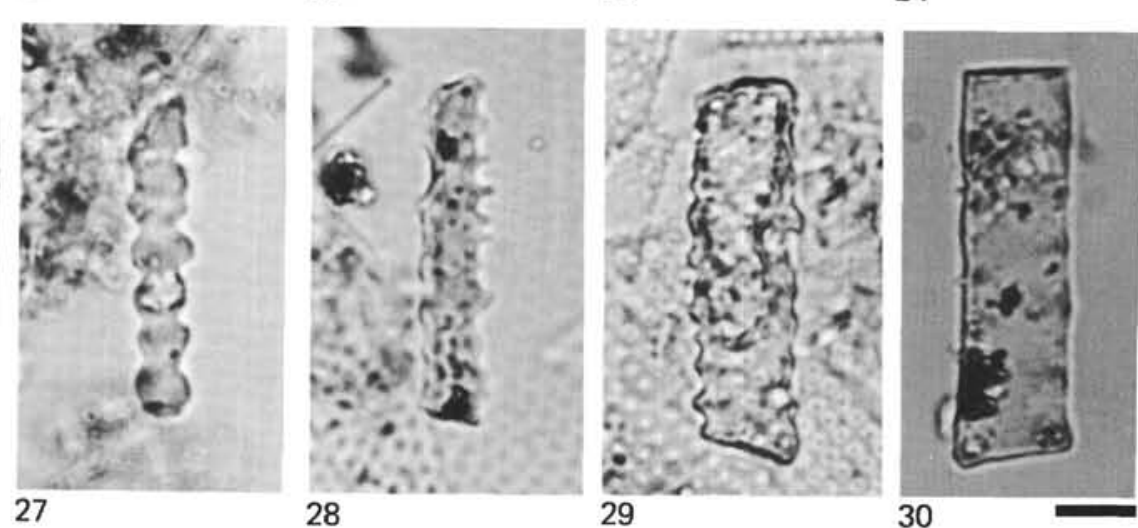


\section{PLATE 5}

Opal Phytoliths, Grass Slivers, and Pollen from DSDP Leg 54.

Figure 1 magnified $\times 1050$; scale bar equals $10 \mu \mathrm{m}$.

Figures 2-15 magnified $\times 800$; scale bar equals $10 \mu \mathrm{m}$.

Figures 1-7 Elongates.

1. Sample 428-4-5, 74-76 cm (55 m).

2. Sample 425-2-3, 74-76 cm (9 m).

3. Sample $427-8-5,7-8 \mathrm{~cm}(124 \mathrm{~m})$.

4. Sample 420-6-1, 121-123 cm (44 m).

5. Sample $420-2-3,126-128 \mathrm{~cm}(9 \mathrm{~m})$.

6. Sample $420-10-5,122-124 \mathrm{~cm}(88 \mathrm{~m})$.

7. Sample $420-7-4,100-102 \mathrm{~cm}(57 \mathrm{~m})$.

Figures 8, 9 ?Radiolarian fragment or opal phytolith.

8. Sample 428-4-3, 74-76 cm (52 m).

9. Sample 420-9-1, 124-126 cm (72 m).

Figures 10-13 Grass slivers.

10. Sample 428-4-5, 74-76 cm (55 m).

11. Sample 420-13-1, 124-126 cm (110 m).

12. Sample $425-2-3,74-76 \mathrm{~cm}(9 \mathrm{~m})$.

13. Sample $420-9-5,124-126 \mathrm{~cm}$ (78 m).

Figure 14 ?Opal phytolith.

Sample 419-5-2, 69-71 cm (31 m).

Figure 15 Pollen.

Sample 420-6-3, 122-124 cm (47 m). 
PLATE 5
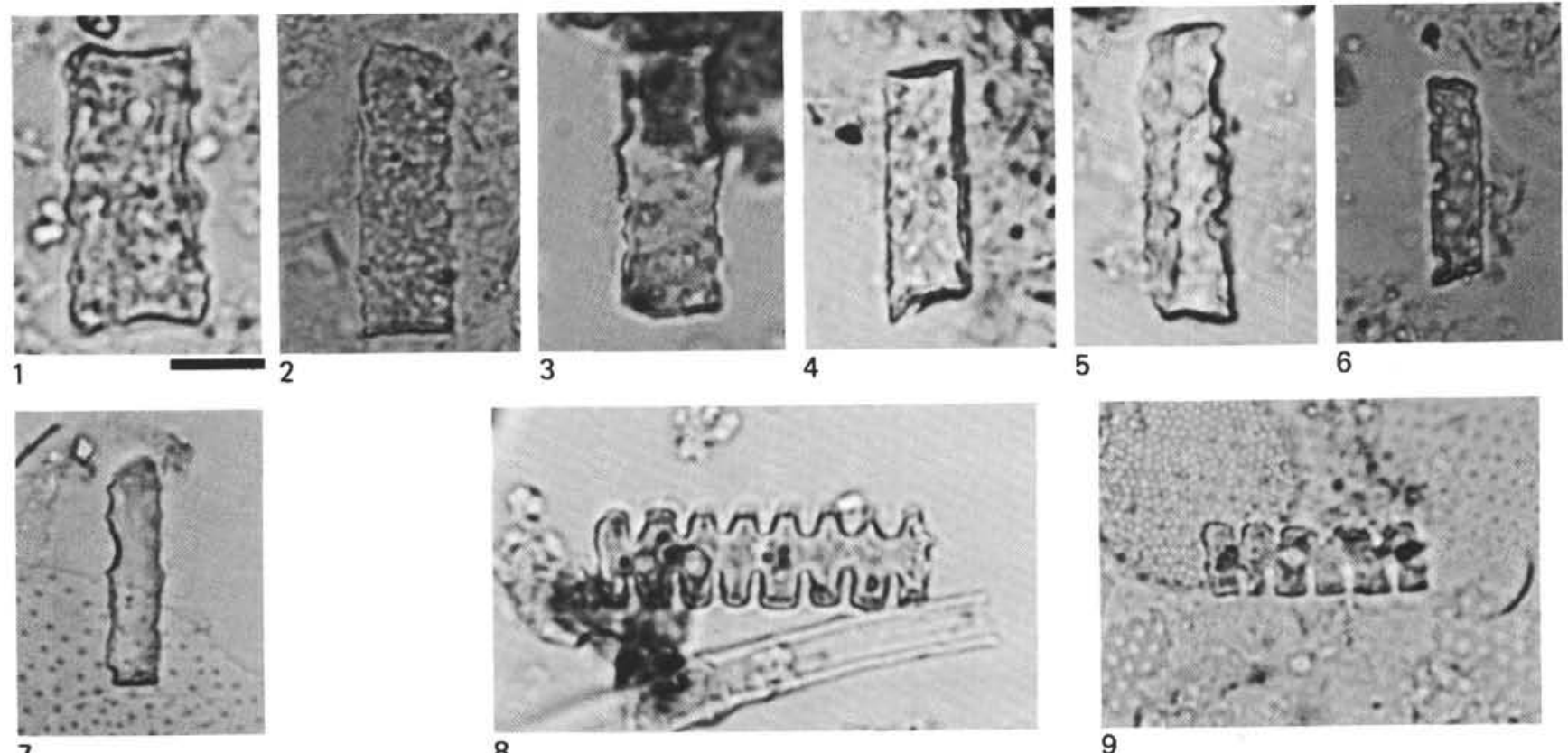

8
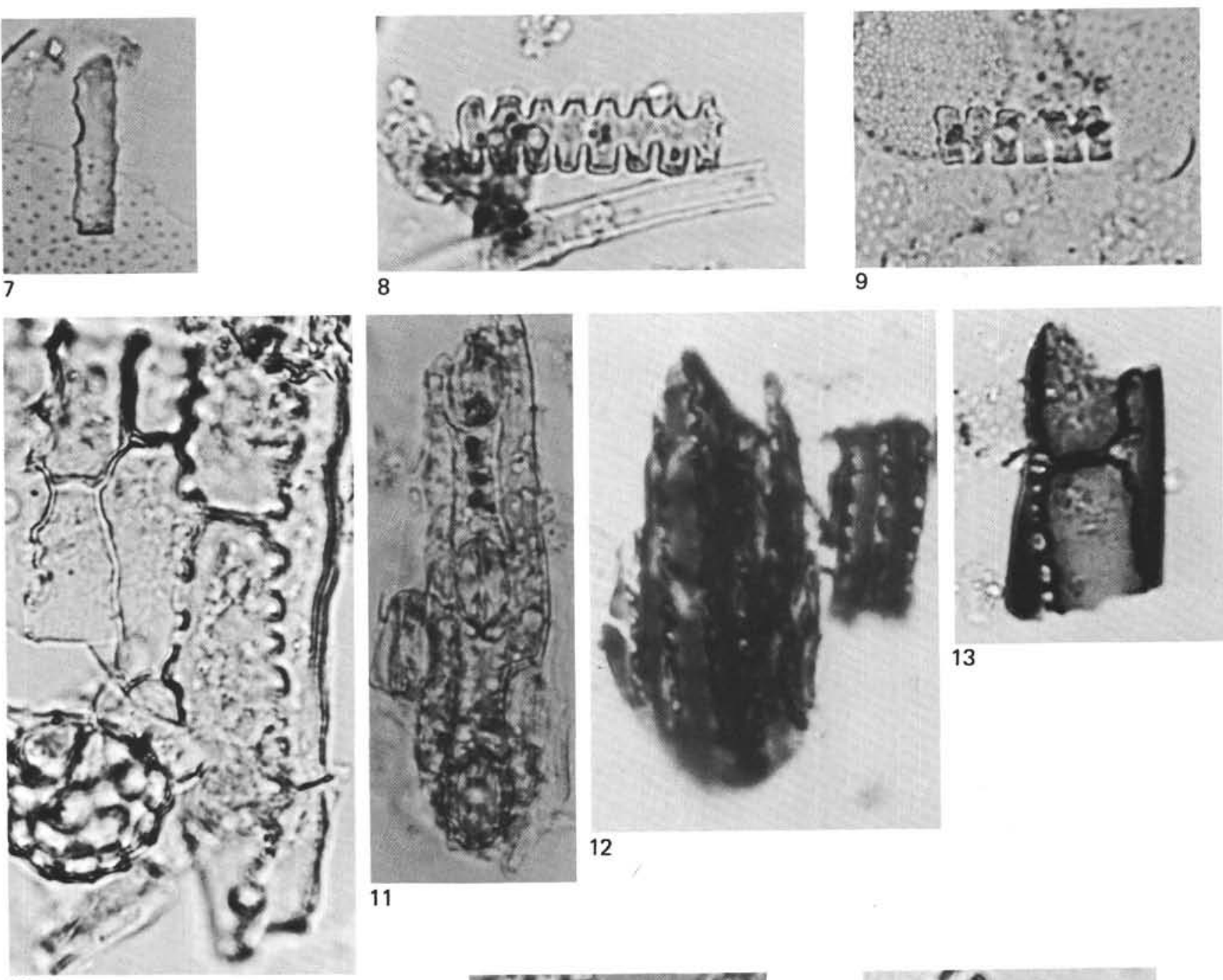

13

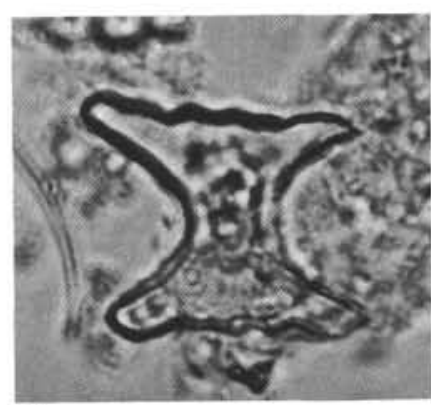

14

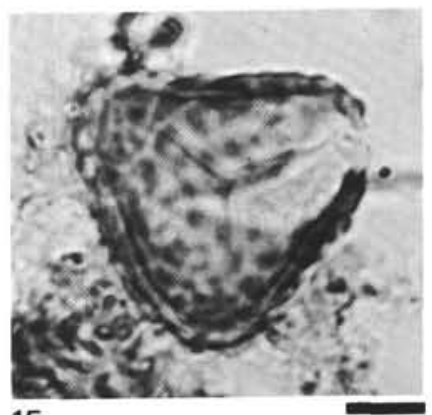

15 